\title{
DOE/FETC/G-98/7307
}

\section{CHARACTERIZATION OF HOT-GAS FILTER ASH UNDER PFBC OPERATING CONDITIONS}

\section{RECEIVED \\ FEB 021998 \\ OSTI}

\author{
Ann K. Henderson, Michael L. Swanson, John P. Hurley, and Tina M. Watne \\ Energy \& Environmental Research Center \\ University of North Dakota \\ Grand Forks, North Dakota
}

\section{ABSTRACT}

The objective of this program was to perform bench-scale dynamic tests of ash formation and long-term ash cake formation in pressurized fluidized-bed combustion (PFBC) systems to help in the development of methods to predict possible filter bridging problems and suggest possible strategies for mitigating these problems. During the program, four ash formation tests using a washed coal from the Consol Enlow Fork mine, with two size distributions of Plum Run dolomite at two different temperatures, were completed under conditions simulating the operation of the American Electric Power (AEP) Tidd PFBC. In addition, the same test matrix, plus two tests using no sorbent, was completed with the Belle Ayr Powder River Basin subbituminous coal, which will be used at the Southern Company Services (SCS) Wilsonville, Alabama, power systems development facility (PSDF).

\section{EQUIPMENT DESCRIPTION}

A pressurized fluidized-bed reactor (PFBR) has been constructed at the Energy \& Environmental Research Center (EERC) to simulate the bed chemistry, ash interactions, and emissions from a PFBC under closely controlled conditions. Figure 1 is a photograph showing the bench-scale hot-gas filter vessel (BHGFV) system on the PFBR. The 1.4-m-tall reactor is constructed of $76.2-\mathrm{mm}$ Schedule 80 Haynes 556 pipe and is extemally heated with three ceramic heaters. A hot cyclone collects the ash and bed material, which are carried out of the reactor. The reactor can operate in a temperature range of $760^{\circ}$ to $925^{\circ} \mathrm{C}$ and at pressures up to $1.15 \mathrm{MPa}$.

Typical gas and coal feed rates range from 600 to $750 \mathrm{sl} / \mathrm{min}$ and 1.4 to $2.3 \mathrm{~kg} / \mathrm{hr}$, respectively. A data acquisition and control system is used to monitor and record all critical pressures, temperanures, flow rates, and emissions. These critical data include the gas flow rates; bed static pressure and differential pressures across the bed and cyclone; and eleven different internal reactor temperatures. These reactor temperatures are located at $6.4,44.5,88.9,127.0,177.8$, $228.6,279.4,381.0,584.2,787.4$, and $1098.6 \mathrm{~mm}$ above the bottom of the reactor. The air and nitrogen flow rates are controlled automatically to flow rate set points. The reactor pressure is automatically controlled to a pressure set point. Continuous emissions sampling of the flue gas measures the levels of $\mathrm{O}_{2}, \mathrm{SO}_{2}, \mathrm{NO}_{x}, \mathrm{~N}_{2} \mathrm{O}$, $\mathrm{CO}, \mathrm{CO}_{2}$, and hydrocarbons.

The filter vessel was designed to handle all of the gas flow from the PFBR at its nominal design conditions. The vessel is approximately $248 \mathrm{~mm} \mathrm{ID}$ and $1.53 \mathrm{~m}$ long (including cone, vessel and cap) and is designed to handle a gas flow of up to $1000 \mathrm{sl} / \mathrm{min}$ at $840^{\circ} \mathrm{C}$ and $1.15 \mathrm{MPa}$. The $25.4-\mathrm{mm}$-thick stainless steel tube sheet

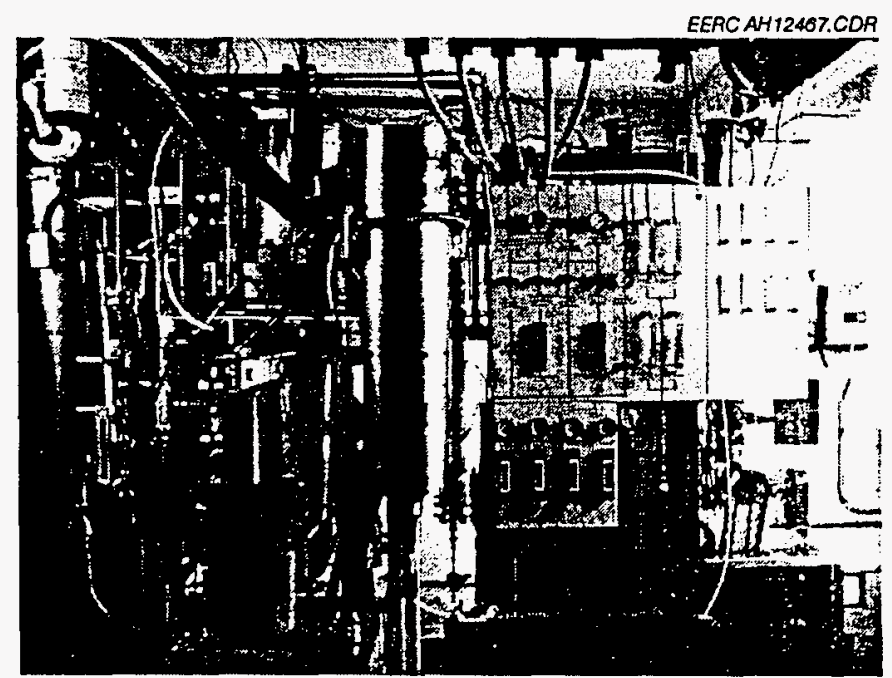

Figure 1. Photograph showing the BHGFV system on the PFBR. 


\section{DISCLAIMER}

This report was prepared as an account of work sponsored by an agency of the United States Government. Neither the United States Government nor any agency thereof, nor any of their employees, makes any warranty, express or implied, or assumes any legal liability or responsibility for the accuracy, completeness, or usefulness of any information, apparatus, product, or process disclosed, or represents that its use would not infringe privately owned rights. Reference herein to any specific commercial product, process, or service by trade name, trademark, manufacturer, or otherwise does not necessarily constitute or imply its endorsement, recommendation, or favoring by the United States Government or any agency thereof. The views and opinions of authors expressed herein do not necessarily state or reflect those of the United States Government or any agency thereof. 
was machined with squared candle filter flanges and stainless steel holddown plates to keep the candles seated. Special adaptors for the candle filters with hemispherical flanges make them interchangeable in the tube sheet. The vessel is sized such that it can handle three candle filters up to $460 \mathrm{~mm}$ long with a $60-\mathrm{mm}$ OD. This provides candle spacing of $98 \mathrm{~mm}$ center line-to-center line and enables filter face velocities as low as $5 \mathrm{~mm} / \mathrm{s}$ to be tested with the PFBR. Higher face velocities are achieved by using fewer or shorter candles or by operating at higher gas flow rates. The data acquisition system for the BHGFV also takes measurements of the gas inlet and exit temperatures, three temperatures in the vessel itself, the flange band heater temperatures, the temperature of each backpulse reservoir, static pressure in the vessel, and the pressure drop across the filters. It is also utilized to initiate the backpulsing sequence.

Two 300-mm-long ceramic candle filters (one each from Industrial Filter \& Pump and 3M Company) and a 380-mm-long candle (from Schumacher) were installed in the vessel prior to ash formation tests. The ceramic candles were sealed in the metal tube sheet using Interam 2600 ceramic material as the sealing gaskets. These gaskets were compressed from approximately 4.32 to $3.30 \mathrm{~mm}$ thick by the holddown plates to provide the seal.

The operational procedure for each test was to verify that the vessels were leak-free before starting the electrical heaters. The reactor and filter vessel heaters were ramped up with the heater controllers to $843^{\circ} \mathrm{C}$, and the filter vessel flange band heaters were ramped up to $540^{\circ} \mathrm{C}$. With an air flow of $170 \mathrm{sl} / \mathrm{min}$ through the reactor and filter vessel at atmospheric pressure, heatup takes about 3 hours. The heaters did a good job of maintaining temperature, although the filter vessel gas temperature was about $100^{\circ} \mathrm{C}$ less than the reactor temperature. The reactor pressure and flows were increased to slightly below their steady-state values before the No. 10 silica sand bed material was fed into the PFBR. After reactor temperatures had stabilized, coal feed was initiated. The standard operating procedure was to perform two ash formation tests for each coal-sorbent combination. The first was the low-temperature test $\left(815^{\circ} \mathrm{C}\right.$ in the bed) followed by the high-temperature test $\left(900^{\circ} \mathrm{C}\right.$ in the bed) using the same coal-sorbent combination. A probe inserted at the reactor outlet was used to collect gas and entrained ash leaving the reactor. The ash was separated from the gas and aerodynamically sized with a multicyclone system. The PFBR was then shut down and all the ash possible recovered before the next test.

\section{TEST PROCEDURES}

Bulk quantities of a washed coal from the Enlow Fork mine (Pittsburgh No. 8 bituminous) and an as-received coal from the Belle Ayr mine (Wyodak subbituminous) were obtained for the ash formation testing. Table 1 shows the proximate and ultimate analyses of the coal and X-ray fractionation (XRF) analyses of coal ashes and the two sizes of dolomite used for these ash formation tests. The BHGFV was electrically heated to maintain the temperature as close as possible to the reactor temperature. The reactor temperature averaged $815^{\circ} \mathrm{C}$ (low temperature) or $900^{\circ} \mathrm{C}$ (high temperature) $\pm 10^{\circ} \mathrm{C}$ in the bubbling bed region of the reactor and averaged approximately $20^{\circ}$ to $50^{\circ} \mathrm{C}$ higher in the freeboard region of the reactor. Excess air averaged $25 \%$, and the reactor velocity averaged
$0.99 \mathrm{~m} / \mathrm{s}$. The average filter vessel temperature was not significantly affected by the temperature in the reactor because of its high thermal mass. Backpulsing the filters typically resulted in a drop in differential pressure across the filters from about 7.5 to $1.2 \mathrm{kPa}$.

\section{TABLE 1}

As-Received Washed Enlow Fork and Belle Ayr Coal and Dolomite Analysis

\begin{tabular}{|c|c|c|c|c|}
\hline & $\begin{array}{l}\text { Enlow } \\
\text { Fork } \\
\text { Coal, } \\
\text { low ash } \\
\end{array}$ & $\begin{array}{c}\text { Belle Ayr } \\
\text { Subbituminous } \\
\text { Coal } \\
\end{array}$ & $\begin{array}{c}\text { Plum Run } \\
\text { Dolomite, } \\
-20 \text { to } \\
+100 \\
\text { mesh }\end{array}$ & $\begin{array}{l}\text { Plum Run } \\
\text { Dolomite, } \\
-20 \text { mesh }\end{array}$ \\
\hline \multicolumn{5}{|l|}{$\begin{array}{l}\text { Proximate Analysis, } \\
\text { as received, wt \% }\end{array}$} \\
\hline Moisture & 2.2 & 16.7 & $\mathrm{NA}^{1}$ & $\mathrm{NA}$ \\
\hline Volatile Matter & 37.8 & 37.9 & & \\
\hline Fixed Carbon & 52.6 & 40.56 & & \\
\hline Ash & 7.4 & 4.9 & & \\
\hline \multicolumn{5}{|l|}{$\begin{array}{l}\text { Ultimate Analysis, } \\
\text { as received, wt \% }\end{array}$} \\
\hline Carbon & 76.16 & 57.5 & NA & NA \\
\hline Hydrogen & 5.40 & 6.18 & & \\
\hline Nitrogen & 1.35 & 0.70 & & \\
\hline Sulfur & 1.58 & 0.36 & & \\
\hline Oxygen & 8.14 & 30.40 & & \\
\hline Ash & 7.36 & 4.87 & & \\
\hline \multicolumn{5}{|l|}{$\begin{array}{c}\text { Ash Composition, } \\
\% \text { as oxides }\end{array}$} \\
\hline Calcium, $\mathrm{CaO}$ & 3.3 & 26.6 & 67.1 & 66.6 \\
\hline Magnesium, MgO & 0.9 & 7.0 & 27.9 & 27.5 \\
\hline Sodium, $\mathrm{Na}_{2} \mathrm{O}$ & 0.2 & 1.3 & 0.3 & 0.3 \\
\hline Silica, $\mathrm{SiO}_{2}$ & 52.4 & 27.8 & 2.1 & 2.7 \\
\hline Aluminum, $\mathrm{Al}_{2} \mathrm{O}_{3}$ & 24.3 & 13.1 & 0.7 & 1.0 \\
\hline Ferric, $\mathrm{Fe}_{2} \mathrm{O}_{3}$ & 13.7 & 5.5 & 1.1 & 1.3 \\
\hline Titanium, $\mathrm{TiO}_{2}$ & 1.0 & 1.3 & 0.0 & 0.0 \\
\hline Phosphorus, $\mathrm{P}_{2} \mathrm{O}_{5}$ & 0.5 & 1.0 & 0.0 & 0.0 \\
\hline Potassium, $\mathrm{K}_{2} \mathrm{O}$ & 1.6 & 0.3 & 0.3 & 0.3 \\
\hline $\begin{array}{l}\text { Sulfur, } \mathrm{SO}_{3} \\
\text { High Heating Value }\end{array}$ & 1.9 & 16.0 & 0.4 & 0.4 \\
\hline $\begin{array}{l}\text { As-received, } \\
\mathrm{MJ} / \mathrm{kg}\end{array}$ & 31.0 & 22.7 & NA & NA \\
\hline $\begin{array}{l}\text { Moisture-free, } \\
\mathrm{MJ} / \mathrm{kg}\end{array}$ & 31.7 & 27.2 & NA & NA \\
\hline $\begin{array}{l}\text { Loss on Ignition } \\
\text { (as run) }\end{array}$ & NA & NA & 39.8 & 43.1 \\
\hline
\end{tabular}

The average gas emissions for the ash formation tests are shown in Table 2. The values shown are corrected to $3 \% \mathrm{O}_{2}$ and adjusted to account for dilution with the nitrogen added with the fluidizing gas. The emissions were fairly consistent for all the tests, except for a higher $\mathrm{SO}_{2}$ concentration in the first test with the Enlow Fork mine coal and higher $\mathrm{N}_{2} \mathrm{O}$ emissions for the higher-rank coal. The $\mathrm{N}_{2} \mathrm{O}$ emissions did show a significant drop with increasing temperature, typical of large-scale units. The reason for the decrease in $\mathrm{SO}_{2}$ emissions after the first test could be the buildup of an initial layer of 
a calcium-rich filter cake. After the first test (296-1), the $\mathrm{SO}_{2}$ emissions were low enough that very little drop in $\mathrm{SO}_{2}$ was observed across the filters. In the case of the first test, a 15-ppm drop was observed across the filters; however, at the higher temperature, very little difference was seen across the filter vessel. This decrease in $\mathrm{SO}_{2}$ emissions at higher temperatures is due to the fluid bed operating in a better temperature regime for calcination of the dolomite (especially under pressure). The $\mathrm{SO}_{2}$ emissions also varied somewhat for the Enlow Fork mine coal throughout the test, increasing by $\sim 50$ to $80 \mathrm{ppm}$ each time the filter vessel was backpulsed. This is due to the fact that some sulfur capture is taking place in the ash layer on the filters themselves; when this ash layer is diminished through backpulsing, there is less $\mathrm{CaO}$ available for sulfur capture. As the ash layer builds up, the sulfur emissions stabilize again at low levels. This sulfation of the dolomite sorbent in the filter cake on the surface of the candles may play a role in the filter blinding and bridging phenomena seen in hot-gas filter systems.

\section{TABLE 2}

Summary of Washed Enlow Fork and Belle Ayr Combustion Test Average Emissions

\begin{tabular}{llllll}
\hline Fuel: & Enlow Fork Enlow Fork & Belle Ayr & Belle Ayr & Belle Ayr \\
Sorbent: & Coarse & Fine & Fine & Coarse & None
\end{tabular}

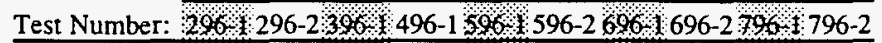

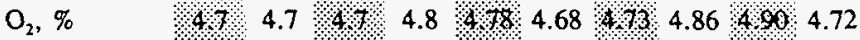

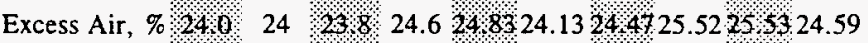

$\mathrm{CO}_{2}, \%^{1} \quad \% .6 .9$ \% $6.6 \%$ \% $8.8 \%$ \% $9.3 \%$ \% 9.2

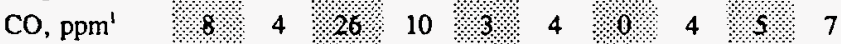

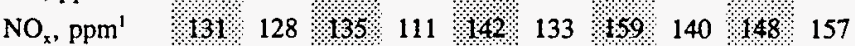

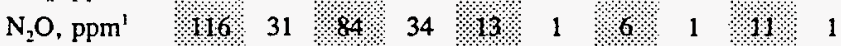

$\begin{array}{llllllll}\mathrm{SO}_{2}, \mathrm{ppm}^{\prime} \quad \sqrt{ } & 2 & 1 & 4 & 11\end{array}$

$S$ Retention,

$\%$

$800999.6 \% 91 \% 97.980 \% 99.01000100 .098 \% 0$ \% 95.1

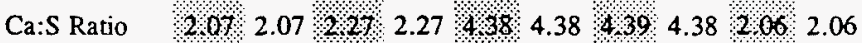
Ca Utilization,

$\% \quad 43048.4 \% 30$ \% $43.322 \% 622.622822 .8 \quad 47 \% 46.2$

Corrected to $3 \% \mathrm{O}_{2}$ and adjusted for $\mathrm{N}_{2}$ dilution.

The total Ca:S ratio for the Belle Ayr coals with the Plum Run dolomite was very high because of the high calcium content of the coal ash. Test 796 was performed to look at the sulfur capture ability of the inherent calcium in the coal ash. The high $\mathrm{Ca}: \mathrm{S}$ ratio resulted in negligible amounts of $\mathrm{SO}_{2}$ emissions from the Belle Ayr coal even when no dolomite was used. No increase in the $\mathrm{SO}_{2}$ emissions was observed for the Belle Ayr mine combustion tests even during backpulsing. This probably was the result of a large excess of calcium in the system overwhelming the effect that backpulsing had on sulfur capture across the filter cake.

Figure 2 shows the particle-size distribution of ash material from the EERC PFBR compared with those obtained from American Electric Power's Tidd PFBR power plant and its advanced particulate filter (APF). The sizes of the filter ashes were measured by laser-light scattering (Malvern), whereas the cyclone and bed materials were sized by sieve. The PFBR bed material is smaller than Tidd's because of the smaller top size of material that can be fed into the PFBR. The cyclone ash from the PFBR is coarser than Tidd's, perhaps because of a shoner relative freeboard height, resulting in the carryover of larger particles from the reactor. The smaller cyclone particle size for the Tidd cyclone ash is also due to the high-efficiency cyclones utilized at Tidd on the gas streams not flowing through the APF capturing a lot of very fine particulate to protect the ruggedized gas turbine. The particle-size distribution of the EERC filter vessel ash tended to run slightly smaller than that found at Tidd after the APF upstream cyclone was removed from service. This indicates that some cyclone spoiling might be needed if the last test segment of the Tidd APF operating conditions is to be duplicated.

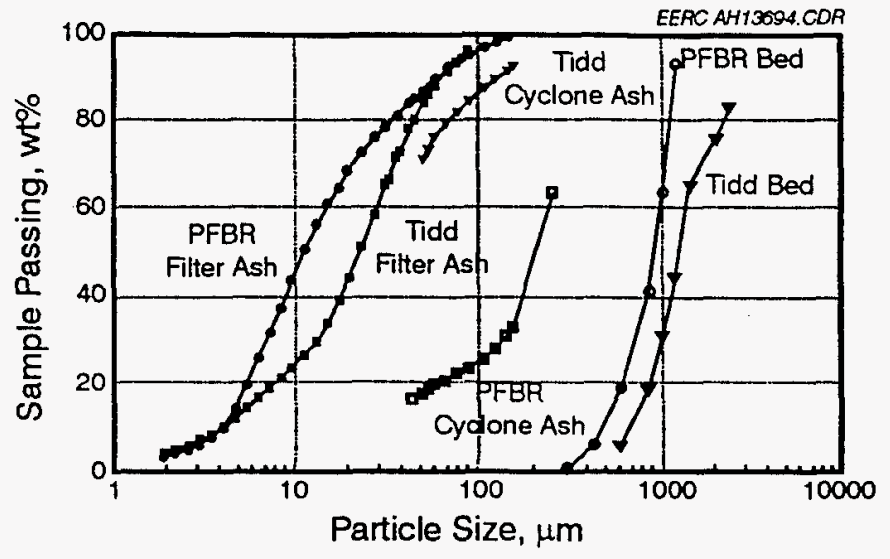

Figure 2. Particle-size distributions of bulk samples from the Tidd PFBC and the EERC PFBR.

Figure 3 compares the chemical composition of the EERC PFBR cyclone and filter vessel ashes obtained at either $815^{\circ}$ or $900^{\circ} \mathrm{C}$ to that obtained from the Tidd cyclone and APF while the fluid bed was operating at $860^{\circ} \mathrm{C}$. From this figure, it appears that there is more calcium in the filter vessel ash at Tidd because of removal of the upstream cyclone, while more of the aluminosilicate material is making it back to the filter vessel on the PFBR. Comparing the cyclone ashes, the $815^{\circ} \mathrm{C}$ combustion test on the PFBR has a chemical composition (excluding the higher silica content due to the initial silica sand start-up bed material) very similar to that of the Tidd cyclone ash, while the higher-temperature test has significantly more calcium and magnesium than the Tidd cyclone ash, possibly due to the calcination and attrition of unconverted calcium/magnesium carbonates at the higher bed temperatures.

Figures 4 and 5 are photographs of the three ceramic candle filters after completion of all the coal combustion tests with each fuel. New candles were installed for each fuel type tested. As shown in these figures, a patchy residual cake did appear to be left on the surface of the candle after the combustion tests using the Enlow Fork mine coal, while very little residual cake appeared to be left after completion of the Belle Ayr mine coal combustion tests. Reasons for this difference are not known at this point; however, future longer-duration cake formation tests will be performed to help answer this question.

Figure 6 displays the chemical composition as determined by scanning electron microscope (SEM) point count (SEMPC) of each 


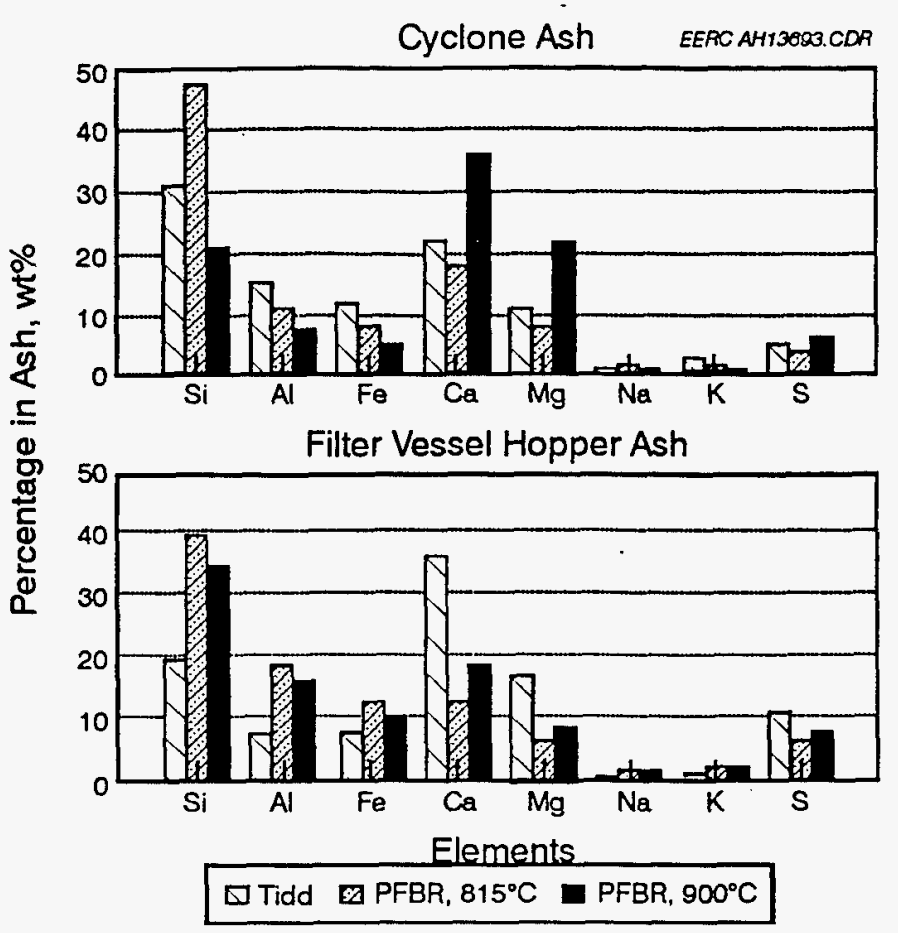

Figure 3. Comparison of the chemical composition of bulk ash samples from the Tidd PFBC and the EERC PFBR.

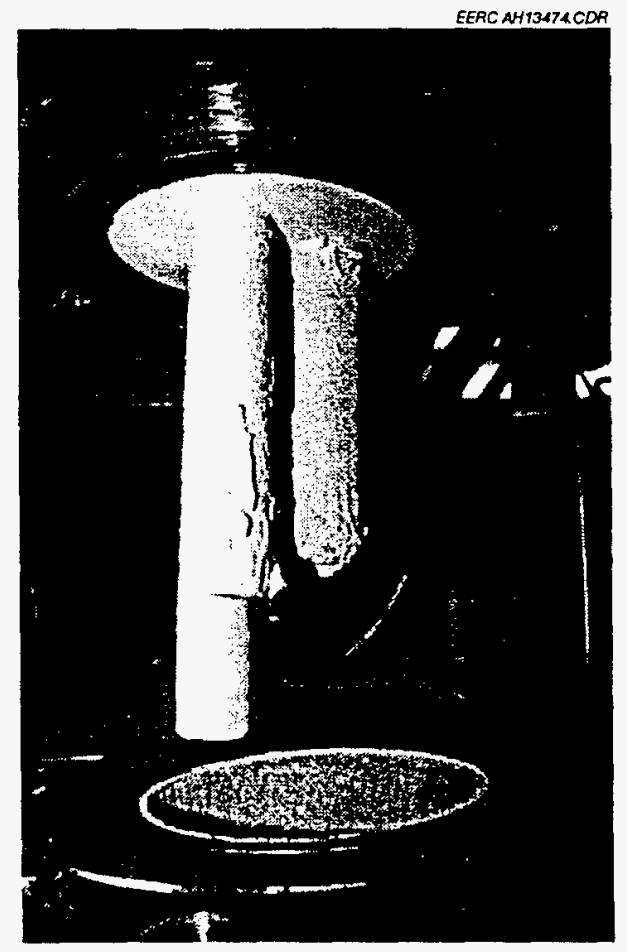

Figure 4. Photograph of the three ceramic candle filters after completion of all Enlow Fork combustion tests.

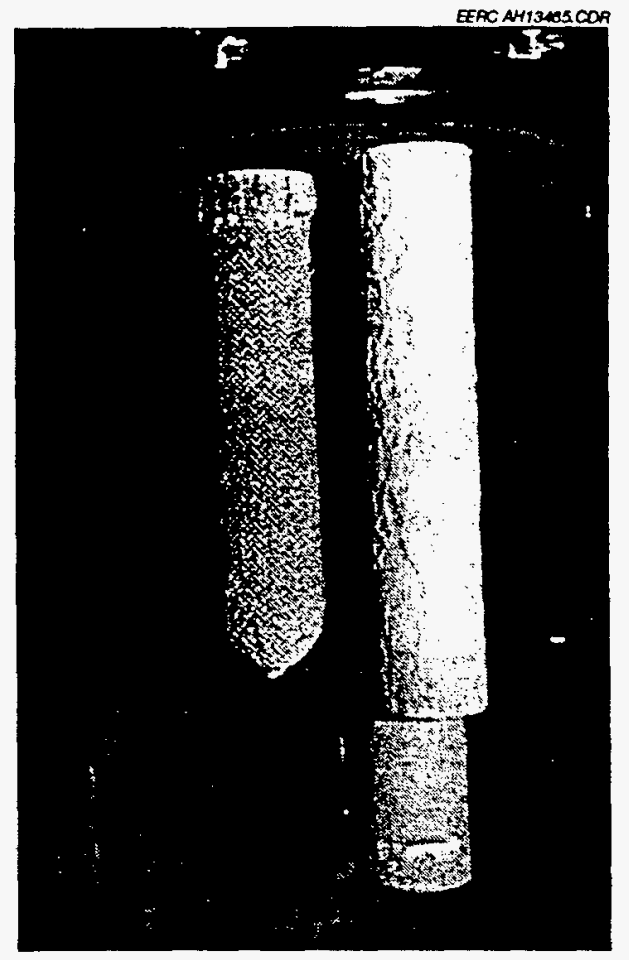

Figure 5. Photograph of the three ceramic candle filters after completion of all Belle Ayr combustion tests.

size fraction collected in the multicyclone train and on the final filter for the washed Enlow Fork mine combustion tests. This figure shows that most of the dolomite sorbent is in the size fraction captured by Cyclone 1, although some slips through to Cyclones 3 and 5 during the fine sorbent tests. The Cyclone 3 and 5 samples are relatively enriched in aluminosilicates and pyrite ash particles. In the final filter, especially for the high-temperature test, there is significantly more sulfur in the smallest size fraction than there is $\mathrm{Mg}$ and $\mathrm{K}$ to tie up the sulfur as sulfates, which suggests that a significant portion of the sulfur is tied up with the aluminosilicate phase (possibly as sodalites).

Figure 7 shows the chemical compositions of the different size fractions of ash collected during the Belle Ayr coal tests. There was little difference in ash composition among the Belle Ayr combustion tests, except for the no-dolomite test, which showed less $\mathrm{Ca}$ and $\mathrm{Mg}$ and more $\mathrm{Si}$ and $\mathrm{Al}$ in the first cyclone compared to the tests with dolomite. In all the smaller cyclones and final filters, the analyses were very similar. It is interesting to note that the smallest size fraction (final filter) is comprised almost entirely of $\mathrm{NaSO}_{4}$, with small amounts of calcium and potassium sulfates. These sulfates can be relatively sticky at the operating conditions seen in the hot-gas filter vessel, especially at the higher temperatures. Figures 8 and 9 compare the fuel types at different temperatures for fine and coarse dolomite, respectively.

These figures show significantly more calcium in the finer ash for the Belle Ayr than for the washed Enlow Fork coal ash. This higher level of calcium is due to the high concentration of organically 


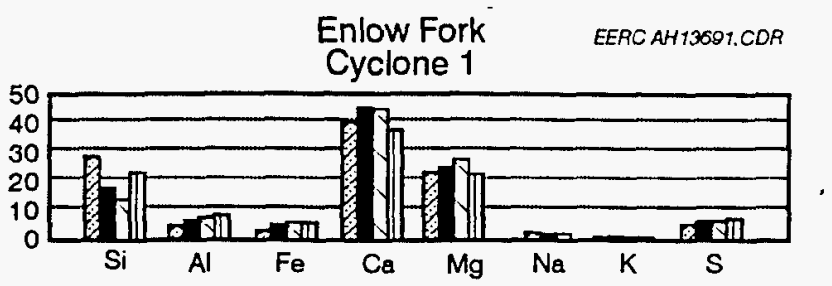

Cyclone 3

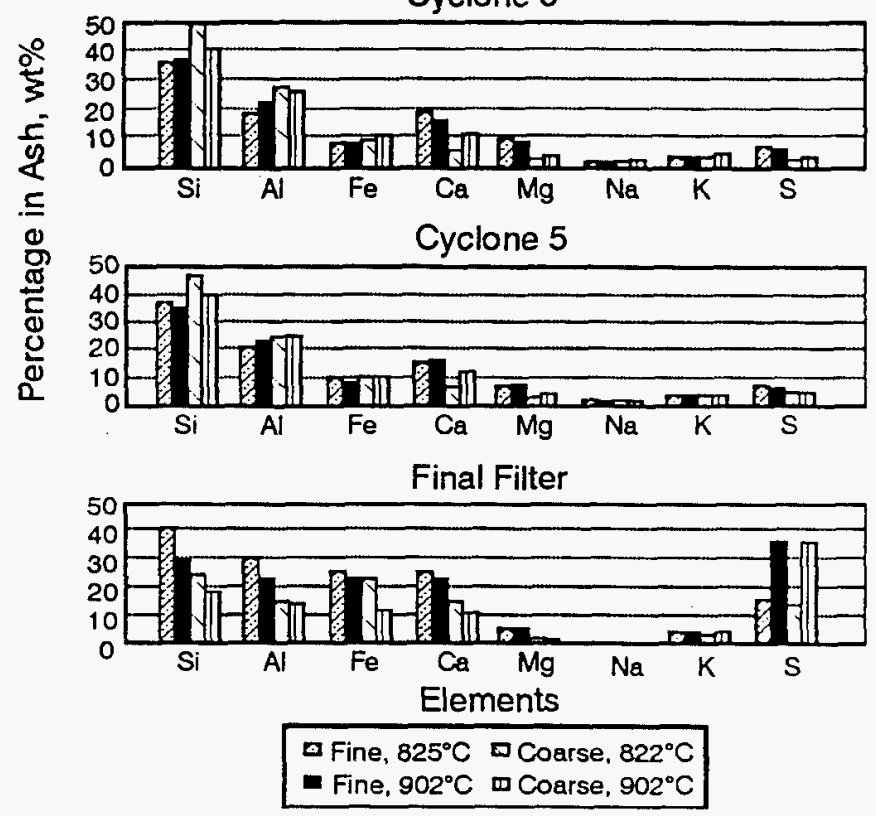

Figure 6. Chemical composition of particulate samples for Enlow Fork combustion tests using two dolomite sizes and two temperatures.

associated calcium in the Belle Ayr coal ash, which vaporizes during combustion and recondenses as small particles. The final filters for both fuels are high in sulfur; however, the Belle Ayr materials appear to be mostly sodium sulfate, while the washed Enlow Fork fuel is made up of aluminosilicate with a small amount of $\mathrm{MgSO}_{4}$ or $\mathrm{K}_{2} \mathrm{SO}_{4}$. which could be present as small particles or coatings or chemically: associated with the aluminosilicate in the form of a sodalite.

\section{CONCLUSIONS}

The PFBR/BHGFV system worked well, and aerodynamically sized particulate samples were obtained from the outlet of the PFBR. Four ash formation tests using the washed Enlow Fork mine coal with the two size distributions of Plum Run dolomite at two different temperatures were completed. In addition, the same two sorbent sizes and temperatures were tested with Belle Ayr mine Powder River Basm subbituminous coal, along with two additional Belle Ayr coal combustion tests using no sorbent to investigate the sulfur capture effects from the high level of calcium present in the coal ash. Results from multicyclone particulate sampling indicate that high operating temperature and the fine dolomite produced a finer ach size distribution for the washed Enlow Fork bituminous coal. However, for the Belle Ayr subbituminous coal, operating temperature and dolomite

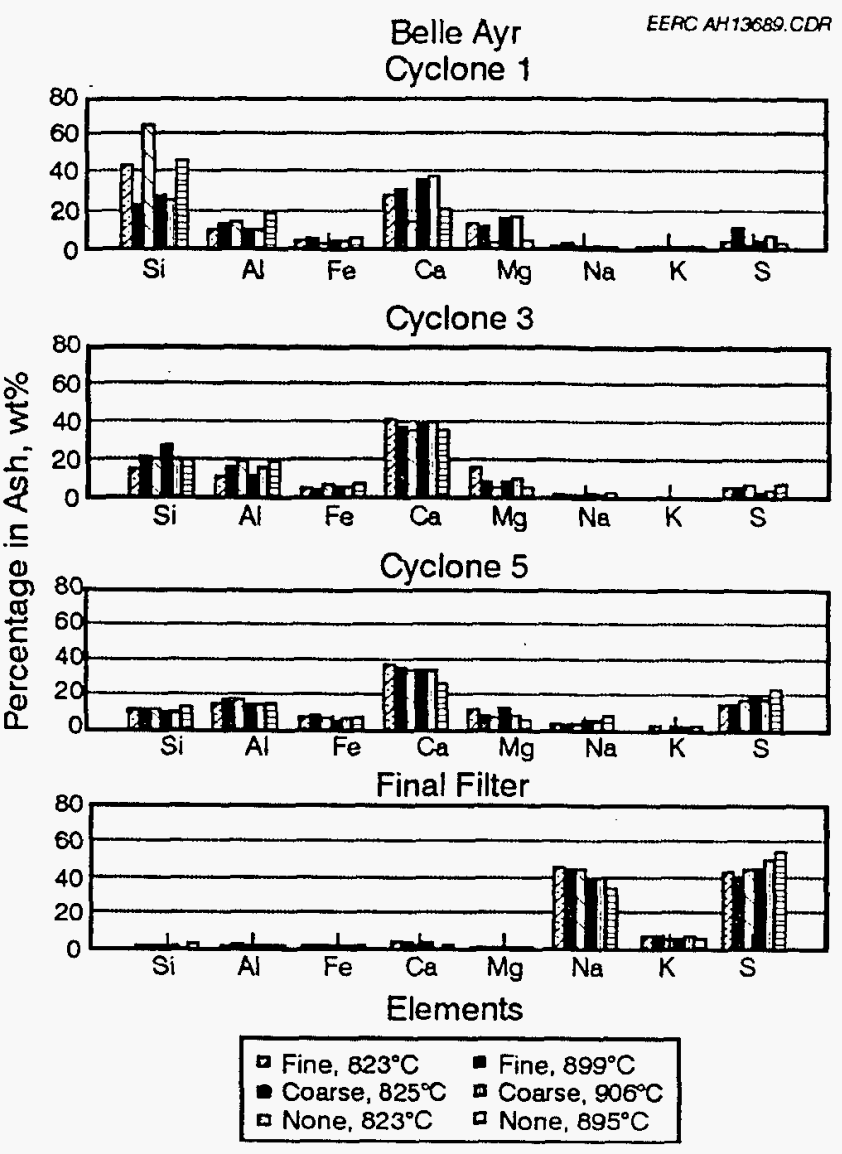

Figure 7. Chemical composition of particulate samples for Belle Ayr combustion tests using three dolomite conditions and two temperatures.

size or even the presence of dolomite appeared to have no significant effect on the particle-size distribution of fly ash leaving the reactor. In general, the greatest effect on ash size and composition is due to the coal type. The Belle Ayr coal produced a finer ash particle-size distribution than the washed Enlow Fork coal because of the presence of more organically associated cations in the Belle Ayr coal.

The chemical composition of the multicyclone particulate samples shows that most of the dolomite is removed in the coarsest size range of the multicyclone train. A large part of the aluminosilicate minerals in the Enlow Fork combustion tests was removed in the smaller size fractions, while the finest size fraction (final filter) was determined to be a sulfur-rich aluminosilicate with small amounts of potassium or magnesium sulfate present. This composition suggests the presence of a sodalite-type compound, which might have some lower melting temperatures. The finer ash from the Belle Ayr tests was much more enriched in calcium than the fine ash from the Enlow Fork coal tests because of the organically associated calcium in the Belle Ayr coal that vaporizes and condenses as small particles during coal combustion. The smallest size fraction (final filter) of the Belle Ayr ash was mainly sodium sulfate, which can melt in the temperature range at which these filters are operating. 


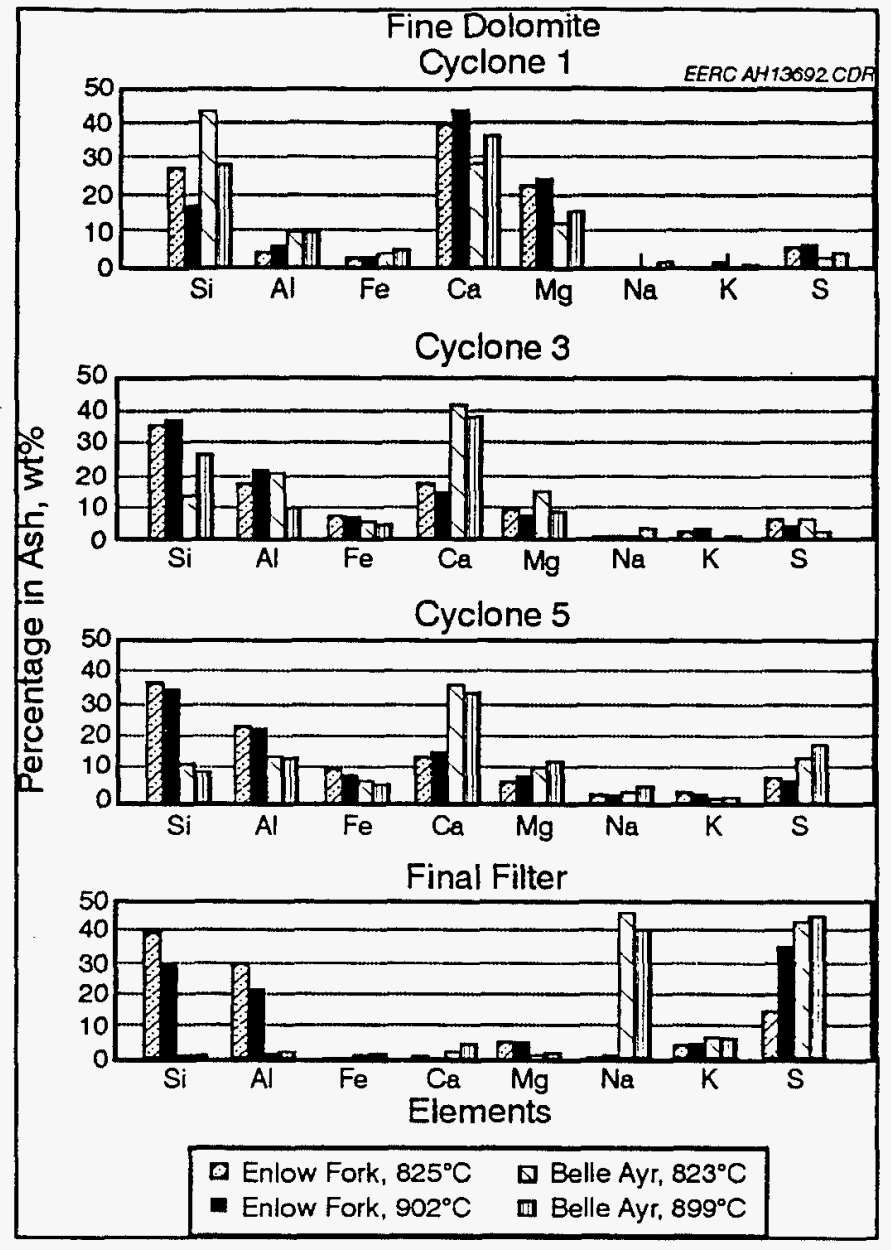

Figure 8. Chemical composition of particulate samples for fine dolomite tests using two fuels and two temperatures.

\section{ACKNOWLEDGEMENTS}

The EERC would like to acknowledge the following companies and organizations whose contributions and support made this work possible: the Electric Power Research Institute, ABB/Carbon AB. Electric Power Development Company, Lid.. Electricite de France/DER, Lurgi Lentjes Babcock, Netherlands Energy Research Foundation, Novem, PowerGen, Schumacher Filters America. Schumacher Umweldt-und Trennetechnik GmbH, the U.S. Deparment of Energy, and Westinghouse STC.

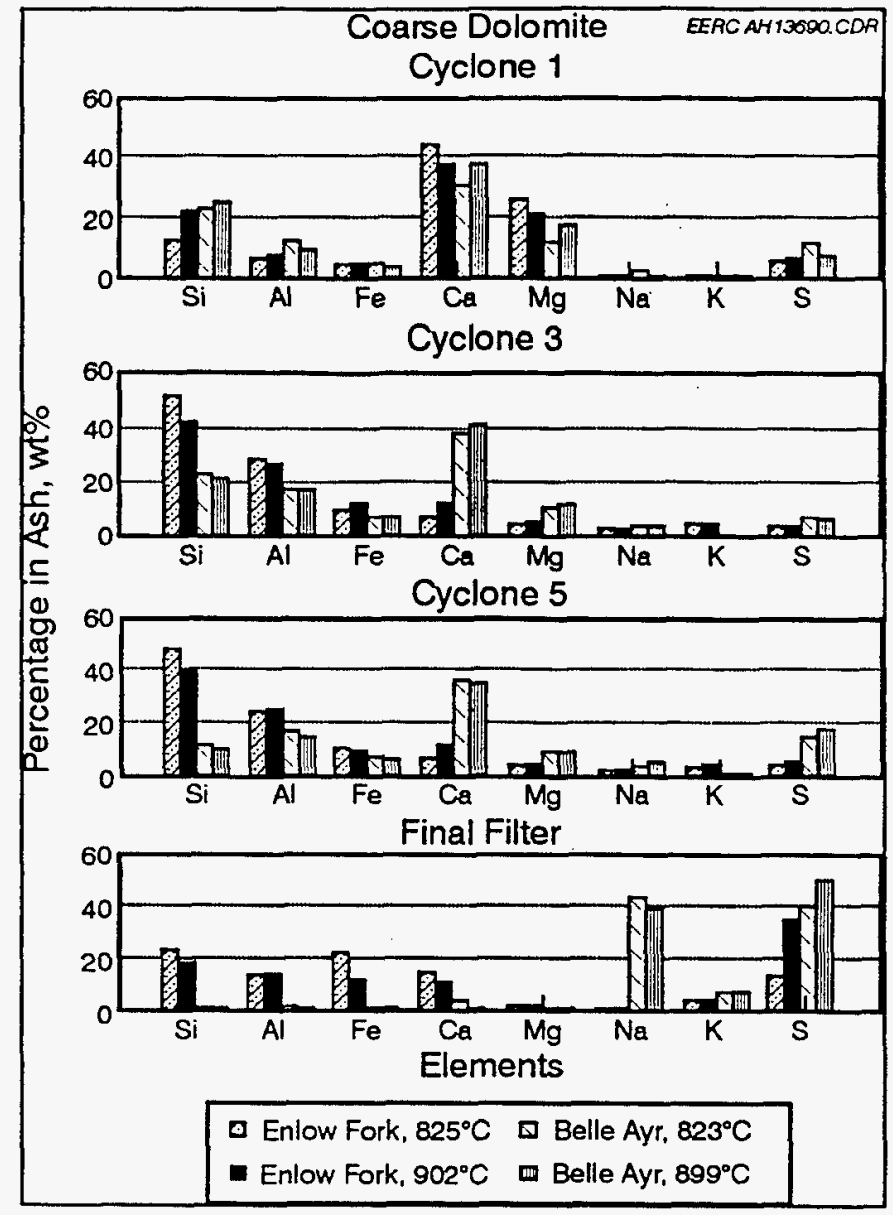

Figure 9. Chemical composition of particulate samples for coarse dolomite tests using two fuels and two temperatures. 


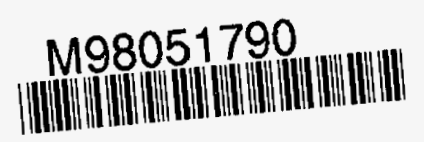

$$
\begin{aligned}
& \begin{array}{l}
\text { Report Number (14) DOE/FETC/C- }-98 / 7307 \\
\text { CONE-9705236- }
\end{array} \\
& \text { Publ. Date (11) } \frac{199801}{\text { Sponsor Code (18) }} \\
& \text { UC Category (19) UC-1O, DOE)ER }
\end{aligned}
$$

